\title{
Housing and mothering
}

\section{Their effects upon the developmental levels of 3-year-old children}

\author{
MARGARET POLLAK \\ The Sir Wilfrid Sheldon Assessment Centre, London
}

SUMMARY The development of 200 3-year-old children was measured, using Gesell parameters of development. The levels of development were matched against the adequacy, or inadequacy, of maternal care and housing, the scales for which were derived from a questionnaire completed by the children's mothers. Housing was not found to affect the children's developmental levels, while the adequacy of maternal care was highly significantly related to satisfactory child development.

Be it castle or city slum, there is no place like home. Does research support this view? It is not easy to differentiate between the facilities of a home and the quality of care therein, and many research studies have failed to make this important distinction. The evidence that is available on the relative importance to a child of his mother and his home is somewhat conflicting. Several studies (Kaufman and Rosenblum, 1969; Spencer-Booth and Hinde, 1971a, b) have shown that monkeys who remained in their own 'homes' were distressed when their mothers were taken away, suggesting that the mother was more important than the home. Ross and Simpson (1971), on the other hand, found no intellectual retardation after the death of a parent if the child remained at home in familiar surroundings. When monkeys and children are removed from their homes they suffer distress (Edelston, 1943; Bakwin, 1949; Mac Keith, 1953; Robertson, 1958), but it is well known that this can be lessened if the mother accompanies the child to the new environment (Prugh et al., 1953; Illingworth and Holt, 1955; Fagin, 1966).

A 'poor' home has been associated with poor educational achievement (Douglas, 1964; Department of Education and Science, 1967), backwardness (Burt, 1937), delinquency (Ferguson, 1966; West and Farrington, 1973), and psychiatric disorder (Rutter, 1976). However, the exact factors in the 'poor' homes which are important for the associations have not been defined.

Few studies have attempted to compare housing and maternal factors with measurable developmental levels in preschool children. But, if it were possible to separate housing conditions from parent care

The Sir Wilfrid Sheldon Assessment Centre, London MARGARET POLLAK, consultant paediatrician and to compare each of these factors with measured developmental parameters, comments could be made upon the relative importance of them on child development.

\section{Present study}

This cross-cultural study was made on 200 3-yearold children. 150 of them were born in the United Kingdom to 75 English parents and 75 West Indian parents. They were all living in the same district of south London, they came from similar social classes, and there were no significant differences in income levels. They have been described in detail elsewhere (Pollak, 1972). The remaining 50 children were living in North Carolina, USA and comprised 25 children born to white American parents and 25 born to negro American parents. These 50 children and their parents were in receipt of 'welfare'.

The 200 children were given 56 different paediatric development tests in their own homes in the presence of their mothers (or permanent mother figure). The tests, derived from Gesell (1954) and recorded (Pollak, 1972), were divided into sections to assess motor, personal-social, adaptive, and language parameters of development. The mothers filled in a questionnaire and from this, a scale of housing and maternal care was made.

\section{Housing scale}

1. The house was not multioccupied-i.e. not more than two families lived in the same house. If a flat or apartment, only one family occupied the rooms.

2. The main living room was large enough and had sufficient equipment to enable all the 
members of the family to sit down to a meal together.

3. The family had its own kitchen with running cold water.

4. The family had its own indoor water closet.

5. There was a usable bathroom for exclusive use of the family.

6. The 3-year-old child slept in his/her own cot or bed.

7. The parents and children had separate bedrooms.

8. Children of different sexes had different bedrooms.

9. There was a garden or play area in which the 3-year-old child could play.

10. The accommodation was self-contained with its own front door. Almost all the children in the USA study were in self-contained houses but they were isolated in lonely rural areas, so their point was scored if the nearest general store was within one mile.

\section{Maternal care scale}

1. The 3-year-old child was regularly put to bed by a parent.

2. The child had been given a present or treat for his/her birthday.

3. The mother stated that she spent at least half an hour each day playing with the child.

4. When the child misbehaved he/she was not beaten with a stick or belt, nor had he/she received more than one major punishment during the previous week. (A negative answer to both questions was necessary to qualify for the point.)

5. The mother knew the name of one current television programme for children and watched it with the child at least once a week. (Every household except one had a television set.)

6. During the $1 \frac{1}{2}$-hour interview the mother had appeared warm towards the child and had not shouted at him/her.

7. Three toys belonging to any child in the household had been shown to the examiner.

8. The mother was asked an open-ended question to describe her child in 5 different ways according to his/her character and behaviour. Two or more favourable replies scored one point. For example:

Favourable

'He's very loving, not selfish, got real good manners'.

'She's more for her dad, but very loving and sweet'.
'Oh, he's lovely. Very good most of the time but likes his own way-don't we all?'

\section{Unfavourable}

'Only gives you trouble. Only good when you belt him'.

'Everything about him is bad. He just don't give you no mind'.

'She is very rude. She is stubborn and lazy'.

9. If the mother went out to work she had made appropriate and firm arrangements for the child. In cases where the mother did not work but went out socially without the child, he/she was not left alone in the house or left casually in the charge of another child who was under age 14 years.

10. The child did not have to share his mother's attention with more than two other preschool children.

11. The mother was rated on a 4-point scale by the author for her understanding of and competence in carrying out the needs of the 3-year-old child. Among the factors considered, warmth, hostility towards the child, patience, and teaching skills had high priority.

The total possible score for housing was 10 and, for statistical purposes, a score of 6 or more was considered adequate, while 5 or less was inadequate.

For maternal care, the total possible score was 14 . Eight or more was deemed adequate, while 7 or less was inadequate.

Table 156 development tests

\begin{tabular}{ll}
\hline Development & Top possible score \\
\hline Motor & 15 \\
Personal-social & 10 \\
Adaptive & 12 \\
Language & 14 \\
\hline
\end{tabular}

The developmental levels of the children in these 4 parameters were then matched against the adequacy or inadequacy of the maternal care and housing scales.

\section{Results}

Housing. The development levels of the children were compared with the housing scores. In motor, personal-social, and adaptive development there was no significant difference between the scores when the housing was adequate or inadequate. Only in the case of the West Indian 3-year-old children did inadequate housing significantly lower the development score in language development (Table 2). 
Table 2 Developmental scores of 200 3-year-old children, matching adequate housing against inadequate housing

\begin{tabular}{|c|c|c|c|c|c|c|c|}
\hline \multirow[t]{2}{*}{ Development } & \multicolumn{2}{|l|}{ Total } & \multicolumn{2}{|c|}{ Inadequate housing } & \multicolumn{2}{|c|}{ Adequate housing } & \\
\hline & Mean score & No. of children & Mean score & No. of children & Mean score & No. of children & \\
\hline \multicolumn{8}{|l|}{ Motor } \\
\hline English & $13 \cdot 27$ & 75 & $13 \cdot 34$ & 15 & $13 \cdot 11$ & 60 & NS \\
\hline West Indian & $12 \cdot 91$ & 75 & $13 \cdot 05$ & 54 & $12 \cdot 77$ & 21 & NS \\
\hline \multicolumn{8}{|l|}{ American } \\
\hline $\begin{array}{l}\text { White } \\
\text { Negro }\end{array}$ & $\begin{array}{l}13 \cdot 0 \\
12 \cdot 5\end{array}$ & $\begin{array}{l}25 \\
25\end{array}$ & $\begin{array}{l}12.9 \\
13.0\end{array}$ & $\begin{array}{r}15 \\
5\end{array}$ & $\begin{array}{l}13 \cdot 0 \\
12 \cdot 2\end{array}$ & $\begin{array}{l}10 \\
20\end{array}$ & $\begin{array}{l}\text { NS } \\
\text { NS }\end{array}$ \\
\hline \multicolumn{8}{|l|}{ Personal-social } \\
\hline English & $8 \cdot 9$ & 75 & $8 \cdot 84$ & 15 & $8 \cdot 94$ & 60 & NS \\
\hline West Indian & $7 \cdot 0$ & 75 & $7 \cdot 15$ & 54 & 6.85 & 21 & NS \\
\hline \multicolumn{8}{|l|}{ American } \\
\hline $\begin{array}{l}\text { White } \\
\text { Negro }\end{array}$ & $8 \cdot 4$ & 25 & $8 \cdot 3$ & 15 & $8 \cdot 5$ & 10 & NS \\
\hline $\begin{array}{c}\text { Negro } \\
\text { Language }\end{array}$ & $7 \cdot 1$ & 25 & $7 \cdot 07$ & 5 & $7 \cdot 16$ & 20 & NS \\
\hline \multicolumn{8}{|l|}{ Language } \\
\hline West Indian & 3.85 & 75 & 3.47 & 54 & $\begin{array}{r}12.12 \\
4.23\end{array}$ & 21 & $\mathrm{P}<0.05$ \\
\hline \multicolumn{8}{|l|}{ American } \\
\hline $\begin{array}{l}\text { White } \\
\text { Negro }\end{array}$ & $10 \cdot 0$ & 25 & $9 \cdot 8$ & 15 & $10 \cdot 3$ & 10 & NS \\
\hline $\begin{array}{c}\text { Negro } \\
\text { Adaptive }\end{array}$ & $5 \cdot 24$ & \multicolumn{4}{|c|}{ Adaptive } & 20 & NS \\
\hline English & $10 \cdot 2$ & 75 & 9.97 & 15 & $10 \cdot 43$ & 60 & NS \\
\hline West Indian & $3 \cdot 5$ & 75 & $3 \cdot 82$ & 54 & $3 \cdot 16$ & 21 & NS \\
\hline \multicolumn{8}{|l|}{ American } \\
\hline $\begin{array}{l}\text { White } \\
\text { Negro }\end{array}$ & $8 \cdot 6$ & 25 & $9 \cdot 1$ & 15 & $8 \cdot 2$ & 10 & NS \\
\hline Negro & $6 \cdot 7$ & 25 & $5 \cdot 8$ & 5 & $7 \cdot 26$ & 20 & NS \\
\hline
\end{tabular}

Maternal care. A very different picture emerged when the children's developmental levels were compared with the maternal care scales. For all groups of children adaptive, language, and personal-social development were highly significantly related to the adequacy or inadequacy of maternal care. For the West Indian children motor development was also affected. In all cases, inadequate maternal care was related to a lower developmental score (Table 3).
Maternal care versus housing. For the children of this study the quality of maternal care was vital for their levels of development, but the adequacy of housing was not of similar importance (Table 4). Furthermore, the adequacy of maternal care was not found to be synonymous with adequacy of housing. A correlation graph (Figure) shows that the adequate mothers were not necessarily the mothers who were living in adequate housing.

Table 3 Developmental scores of 200 3-year-old children, matching adequate maternal care against inadequate maternal care

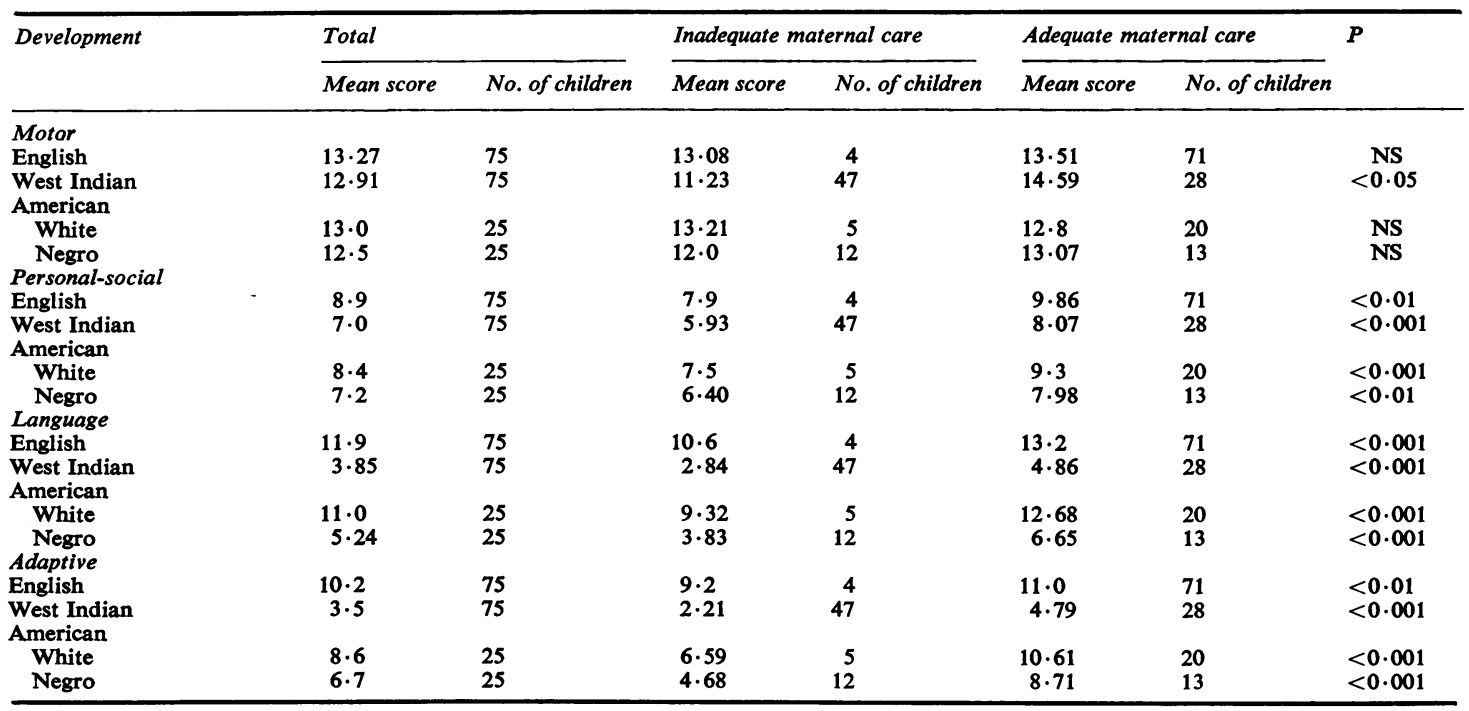


Table 4 Developmental scales matched against the housing and maternal care scales

\begin{tabular}{|c|c|c|c|c|}
\hline & \multirow[t]{2}{*}{ English } & \multirow{2}{*}{$\begin{array}{l}\text { West } \\
\text { Indian }\end{array}$} & \multicolumn{2}{|l|}{ American } \\
\hline & & & White & Negro \\
\hline $\begin{array}{l}\text { Housing } \\
\text { Motor } \\
\text { Personal-social } \\
\text { Language } \\
\text { Adaptive }\end{array}$ & $\begin{array}{l}\text { NS } \\
\text { NS } \\
\text { NS } \\
\text { NS }\end{array}$ & $\begin{array}{c}\text { NS } \\
\text { NS } \\
\mathrm{P}<0.05 \\
\text { NS }\end{array}$ & $\begin{array}{l}\text { NS } \\
\text { NS } \\
\text { NS } \\
\text { NS }\end{array}$ & $\begin{array}{l}\text { NS } \\
\text { NS } \\
\text { NS } \\
\text { NS }\end{array}$ \\
\hline $\begin{array}{l}\text { Maternal care } \\
\text { Motor } \\
\text { Personal-social } \\
\text { Language } \\
\text { Adaptive }\end{array}$ & $\begin{array}{l}\quad \text { NS } \\
\mathbf{P}<0.01 \\
\mathbf{P}<0.001 \\
\mathbf{P}<0.01\end{array}$ & $\begin{array}{l}P \quad 0.05 \\
P<0.001 \\
P<0.001 \\
P<0.001\end{array}$ & $\begin{array}{c}\text { NS } \\
\mathbf{P}<0.001 \\
\mathbf{P}<0.001 \\
\mathbf{P}<0.001\end{array}$ & $\begin{array}{c}\text { NS } \\
\mathbf{P}<0.01 \\
\mathbf{P}<0.001 \\
\mathbf{P}<0.001\end{array}$ \\
\hline
\end{tabular}

\section{Discussion}

It may appear a truism that a child's development is highly significantly related to his mother's love and care but is little affected by the circumstances and amenities of his home. However, this is not necessarily the case. A search in the literature for a study with which to compare these results fails to uncover any in which the various parameters of development are subjected to statistical relevance vis-à-vis maternal care and housing. Deprivation of maternal care has been associated with mental health (Bowlby, 1951), retarded language (Rutter and Mittler, 1972), and IQ (Haywood, 1967), but in no case with several parameters of development and housing factors.

It did not prove easy to devise the maternal care scales since the exact factors which contribute towards 'good' maternal care are not known. The factors which made up this scale were: care and attention (4 questions), warmth (2 questions), stimulation and interaction (4 questions), and the 4point subjective rating. Because of the difficulty, direct answers given by the mother to direct questions put to her were used whenever possible. It was felt that as the questioner was the family doctor of all the UK mothers and children and was well known to them and the questions were asked close to other factual questions, the replies received were likely to be correct and many could be confirmed by observation.

In addition to the main conclusions of this study, it is possible to comment on some aspects of the different parameters of development. For example, there is some evidence to suggest that the genetic influence on motor development is strong (Illingworth, 1960; Geber and Dean, 1957, 1964; Pollak and Mitchell, 1974) and, because in this study motor development appears to be little influenced either by the housing or maternal care, both of which are environmental factors, the results could lend indirect support to this theory.

On the other hand, some workers who have been concerned with the environmental factors which affect child development have cited language development as an example of development which can be delayed by environmental factors. When opportunity to learn is meagre, language development can show retardation (Luria and Yudkovitch, 1959; Ausubel, 1963; Bernstein, 1965). This study supports this view but shows decisively that maternal care rather than housing is the significant variable. Clinical experience suggests that language development, alone, depends substantially on environmental factors.

Maternal care is found to have a significant effect upon adaptive development. Gesell and Armatruda (1947) have written 'The term adaptive behaviour is therefore a pertinent one to describe the category of

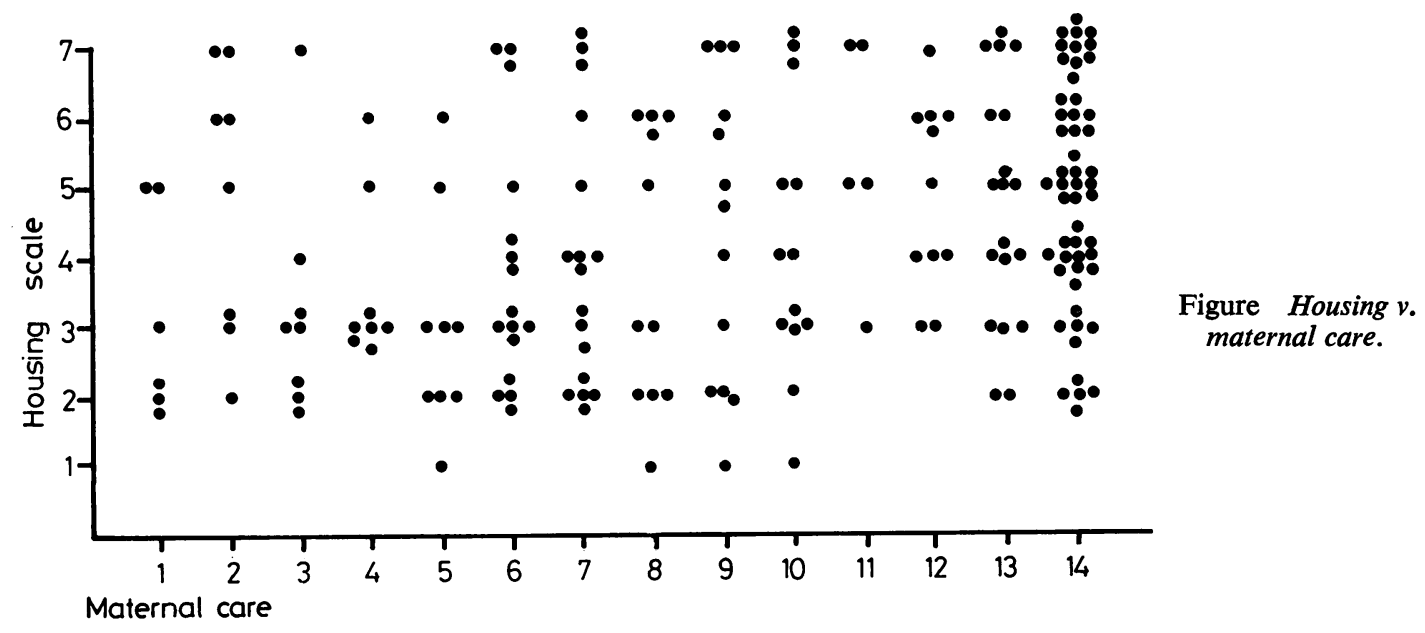


behaviour in young children which most correlates with what in older children is designated intelligence'. If one accepts this statement, then the results of this study suggest that inadequate mothering may carry a grave prognosis.

This research gives no information on the effect of housing upon mothers. Adequate shelter which contains the basic requirements for satisfactory housekeeping is a necessity for every mother and her family and we do not know whether a lack of these necessities caused depression and frustration in some mothers and thus affected, indirectly, her children. It is also not possible to comment on which factors in the maternal care scale were the most important.

The results of this paper put the onus of satisfactory development of the 3-year old firmly on the lap of maternal care and show that the adage 'There is no place like home' is only likely to be true when it contains an adequate mother.

The Statistical Unit of the Royal College of General Practitioners gave statistical advice and help.

\section{References}

Ausubel, D. P. (1963). The Psychology of Meaningful Verbal Learning. Grune and Stratton: New York.

Bakwin, H. (1949). Emotional deprivation in infants. Journal of Pediatrics, 35, 512-521.

Bernstein, B. (1965). A Socio-linguistic Approach to Social Learning. Penguin: Harmondsworth.

Bowlby, J. (1951). Maternal Care and Mental Health. World Health Organisation: Geneva.

Burt, C. (1937). The Backward Child. University of London Press: London.

Department of Education and Science (1967). Plowden Report: Children and Their Primary Schools. A Report of the Central Advisory Council for Education. HMSO: London.

Douglas, J. W. B. (1964). The Home and The School. MacGibbon and Kee: London.

Edelston, H. (1943). Separation anxiety in young children. Study of hospital cases. Genetics and Psychology Monographs, 28, 3-95.

Fagin, C. M. (1966). The Effects of Maternal Attendance During Hospitalisation on the Post-hospital Behaviour of Young Children. A Comparative Study. Davis: Philadelphia.

Ferguson, T. (1966). Children in Care-and Afterwards. Oxford University Press: London.

Geber, M., and Dean, R. F. (1957). Gesell tests on African children. Pediatrics, 20, $1055-1063$.

Geber, M., and Dean R. F. (1964). Le development psychomoteur et somatique des jeunes enfants Africains en Ouganda. Courrier, 14, 425-437.

Gesell, A. (1954). The First Five Years of Life. Methuen: London.
Gesell, A. L., and Armatruda, C. S. (1947). Developmental Diagnosis. Harper and Row: New York.

Haywood, C. (1967). Experimental factors in intellectual development. The concept of dynamic intelligence. In Psychopathology of Mental Development, p. 69. Edited by J. Zubin and G. A. Jervis. Grune and Stratton: New York. Illingworth, R. S. (1960). The Development of the Infant and Young Child, p. 190. Livingstone: Edinburgh.

Illingworth, R. S., and Holt, K. S. (1955). Children in hospital. Some observations on their reactions, with special reference to daily visiting. Lancet, 2, 1257-1262.

Kaufman, I. C., and Rosenblum, L. A. (1969). Effects of separation from mother on the emotional behaviour of infant monkeys. Annals of the New York Academy of Sciences, 159, 681-695.

Luria, A. R., and Yudkovitch, F. Y. (1959). Speech and the Development of Mental Processes. Staples Press: London.

Mac Keith, R. (1953). Children in hospital. Preparation for operation. Lancet, 2, 843-845.

Pollak, M. (1972). Today's Three-year-olds in London. Heinemann/Spastics International: London.

Pollak, M., and Mitchell, S. (1974). Early development of negro and white babies. Archives of Disease in Childhood, 49, 40-45.

Prugh, D. G., Staub, E. M., Sands, H. H., Kirschbaum, R. M., and Lenihan, E. A. (1953). A study of the emotional reactions of children and families to hospitalisation and illness. American Journal of Orthopsychiatry, 23, 70-106.

Robertson, J. (1958). Young Children in Hospital. Tavistock Publications: London.

Ross, J. M., and Simpson, H. R. (1971). National survey of health and development. II. Rate of school progress between 8 and 15 years, and between 15 and 18 years. British Journal of Educational Psychology, 41, 125-135.

Rutter, M. (1976). Prospective studies to investigate behavioural change. In Methods of Longitudinal Research in Psychopathology. Edited by J. Strauss, H. M. Batigan, and M. Ross. Plenum: New York.

Rutter, M., and Mittler, P. (1972). Environmental influences on language development. In Clinics in Developmental Medicine 43: The Child with Delayed Speech, pp. 52-67. Edited by M. Rutter and J. A. M. Martin. Heinemann Medical: London.

Spencer-Booth, Y., and Hinde, R. A. (1971a). Effects of brief separations from mothers during infancy on the behaviour of rhesus monkeys six to twenty-four months later. Journal of Child Psychology and Psychiatry, 12, 157-172.

Spencer-Booth, Y., and Hinde, R. A. (1971b). Effects of 6 days' separation from mother on 18 to 32-week-old rhesus monkeys. Animal Behaviour, 19, 174-191.

West, D. J., and Farrington, D. P. (1973). Who Becomes Delinquent? Second Report of the Cambridge Study in Delinquent Development. Heinemann Educational: London.

Correspondence to Dr Margaret Pollak, The Sir Wilfrid Sheldon Assessment Centre, Kings College Hospital, London SE5 9RS.

Received 18 April 1977 